\title{
Single coronary artery with bicuspid aortic valve
}

\author{
Dominika M Zoltowska, ${ }^{1}$ Yashwant Agrawal, ${ }^{2}$ Guramrinder Singh Thind, ${ }^{1}$ \\ Jagadeesh K Kalavakunta ${ }^{3}$
}

'Department of Internal Medicine, Western Michigan University School of Medicine, Kalamazoo, Michigan, USA ${ }^{2}$ Department of Internal Medicine and Pediatrics, Western Michigan University Homer Stryker School of Medicine, Kalamazoo, Michigan, USA

${ }^{3}$ Department of Cardiology, Borgess Medical Center, Kalamazoo, Michigan, USA

\section{Correspondence to} Dr Dominika M Zoltowska, dominika.zoltowska@med. wmich.edu

Accepted 5 April 2018
Check for updates

To cite: Zoltowska DM, Agrawal $Y$, Thind GS, et al. BMJ Case Rep Published Online First: [please include Day Month Year]. doi:10.1136/bcr-2018225309

\section{DESCRIPTION}

A 45-year-old man with known history of coronary artery disease and bicuspid aortic valve (BAV) (figure 1) was admitted for worsening symptoms of angina. Coronary angiogram showed single coronary artery arising from the left cusp, trifurcating into right coronary artery, left anterior descending (LAD) and left circumflex artery (LCx) (figure 2). No course of the left main coronary artery between the aortic root and the pulmonary artery was noted. There was obstructive disease in proximal LAD (70\%), first diagonal artery (80\%) and proximal LCx (70\%). Peak gradient of $51 \mathrm{~mm} \mathrm{Hg}$ across the BAV was registered. He underwent bypass graft surgery along with an aortic valve replacement successfully.

Single coronary artery is an extremely rare condition with a prevalence ranging from $0.0024 \%$ to $0.044 \%$. This variance may be associated with another congenital heart diseases, decreased myocardial perfusion and increased risk of sudden cardiac death. ${ }^{1}$ Identification of anomalous coronary arteries (ACA) before planned surgery is crucial as it may carry significant technical difficulties. It is also important to recognise the malignant course of ACA as it warrants further evaluation. ${ }^{2}$

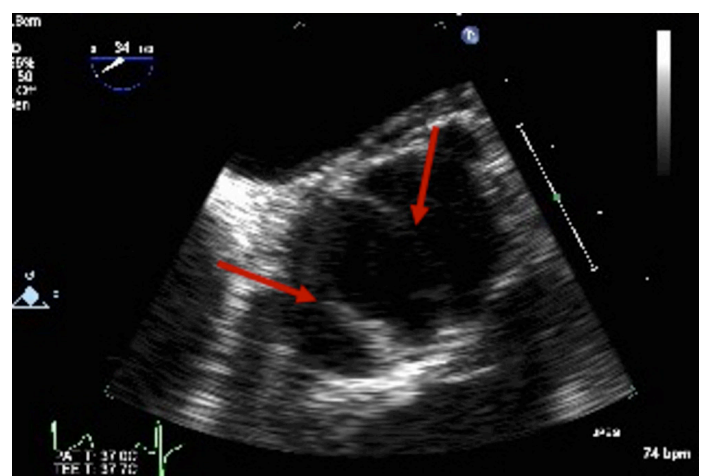

Figure 1 Transoesophageal echocardiogram. Parasternal short axis view revealing bicuspid aortic valve (BAV). Red arrows pointing at aortic valve cusps.

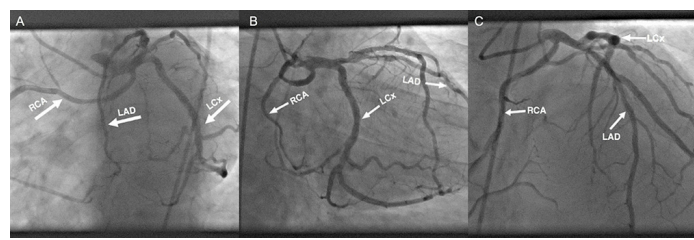

Figure 2 (A) Left anterior oblique (LAO) caudal view. (B) Right anterior oblique (RAO) caudal view. (C) Anteriorposterior (AP) cranial view. LAD, left anterior descending artery; LCX, left circumflex artery; RCA, right coronary artery.

Learning points

- Association between anomalous coronary arteries and other congenital heart disease.

- The importance of recognition of the anomalous coronary arteries anatomy.

Contributors DMZ, YA, GST and JK were the physicians in charge of the patient throughout hospitalisation and follow-up. DMZ and $\mathrm{JK}$ were responsible for performing, diagnosing and discussing the imaging studies of the patient. DMZ prepared the manuscript draft, which was critically revised by YA, GST and JK and approved by all authors.

Funding The authors have not declared a specific grant for this research from any funding agency in the public, commercial or not-for-profit sectors.

Competing interests None declared.

Patient consent Obtained.

Provenance and peer review Not commissioned; externally peer reviewed.

(C) BMJ Publishing Group Ltd (unless otherwise stated in the text of the article) 2018. All rights reserved. No commercial use is permitted unless otherwise expressly granted.

\section{REFERENCES}

1 Topaz O, DeMarchena EJ, Perin E, et al. Anomalous coronary arteries: angiographic findings in 80 patients. Int I Cardiol 1992;34:129-38.

2 Kim SY, Seo JB, Do KH, et al. Coronary artery anomalies: classification and ECG-gated multi-detector row CT findings with angiographic correlation. Radiographics 2006:26:317-33. 
Copyright 2018 BMJ Publishing Group. All rights reserved. For permission to reuse any of this content visit http://group.bmj.com/group/rights-licensing/permissions.

BMJ Case Report Fellows may re-use this article for personal use and teaching without any further permission.

Become a Fellow of BMJ Case Reports today and you can:

- Submit as many cases as you like

- Enjoy fast sympathetic peer review and rapid publication of accepted articles

- Access all the published articles

- Re-use any of the published material for personal use and teaching without further permission

For information on Institutional Fellowships contact consortiasales@bmjgroup.com

Visit casereports.bmj.com for more articles like this and to become a Fellow 